\title{
CRYSTAL STRUCTURE OF CARBONYL TRICHLORO BIS(TRIPHENYL PHOSPHINE) RUTHENIUM(III) COMPLEX
}

\author{
M. Gowri ${ }^{1}, T$. Srinivasan ${ }^{2}, D$. Velmurugan ${ }^{2}$ \\ ${ }^{1}$ Department of Chemistry, Avinashilingam University for Women, Tamilnadu, India \\ E-mail: sriadit.gowrisuresh@gmail.com \\ ${ }^{2}$ CAS in Crystallography and Biophysics, University of Madras, Tamilnadu, India \\ E-mail: srini771@gmail.com,shirai2011@gmail.com
}

The title complex is synthesized and analyzed using single crystal X-ray diffraction studies. The asymmetric unit $\left[\mathrm{RuCl}_{3}(\mathrm{CO})\left(\mathrm{PPh}_{3}\right)_{2}\right]$ of the title complex contains one half of the molecule. The molecular structure is stabilized by $\mathrm{C} 3-\mathrm{H} 3 \ldots \mathrm{Cl} 1$ and $\mathrm{C} 9-\mathrm{H} 9 \ldots \mathrm{Cl} 2$ intramolecular halogen interactions which result in two $\mathrm{S}(6)$ ring motifs. The crystal packing features are the $\mathrm{C}-\mathrm{H} \ldots \mathrm{Cg} 1$ interactions, where $\mathrm{Cg} 1$ is the center of gravity of the phenyl ring $(\mathrm{C} 14-\mathrm{C} 19)$. No classical hydrogen bond is found in the complex.

DOI: $10.15372 / \mathrm{JSC} 20150628$

K e y w o r d s: $\mathrm{Ru}(\mathrm{III})$ complex, triphenyl phosphine $\left(\mathrm{PPh}_{3}\right)$, chloride, carbonyl, single crystal XRD.

Organometallic complexes with bonds that have characters in-between ionic and covalent are very important in industry since they are relatively stable in solutions and relatively ionic to undergo reactions. This is the case of complexes having $\mathrm{CO}$ as one of their ligands $\left[\mathrm{M}=\mathrm{C}=\mathrm{O} \leftrightarrow \mathrm{M}^{+} \equiv \mathrm{C}-\mathrm{O}^{-}\right]$. Phosphines are used as ligands for many metal complexes. The most popular phosphine ligand used is triphenyl phosphine: a shelf-stable solid that relatively slowly undergoes oxidation in air. Unlike most metal ammine complexes, metal phosphine complexes tend to be lipophilic, displaying good solubility in organic solvents. They are found to be compatible with metals in multiple oxidation states. Because of these two features, metal phosphine complexes are important in homogeneous catalysis [1]. Being bonded to the $\mathrm{Ru}(\mathrm{III})$ metal atom in the complexes, the ligands such as triphenyl phosphine, carbonyl, and chloride have characteristic biological activities and they have extensively been studied. Aryl phosphines are much stronger $\pi$ acceptors than alkyl phosphines, which are poor $\pi$ acceptors or possibly $\pi$ donors. Phosphine with the strongest $\pi$ acidity is trifluorophosphine $\left(\mathrm{PF}_{3}\right)$; its $\pi$ acidity approaches that of the carbonyl ligand [2 ]. Phosphine ligands are usually "spectator" rather than "actor" ligands. They generally do not participate in reactions, except the dissociation from the metal center. At a certain high temperature hydroformylation reactions, the scission of $\mathrm{P}-\mathrm{C}$ bonds is observed, however, in few cases [3]. The thermal stability of phosphine ligands is enhanced when they are incorporated into pincer complexes [4].

Based on the views and approaches to the complexes with triphenyl phosphine, carbonyl, and chloride as ligands, we herein investigate the crystal structure of a novel $\mathrm{Ru}(\mathrm{III})$ complex $\left[\mathrm{RuCl}_{3}(\mathrm{CO})\left(\mathrm{PPh}_{3}\right)_{2}\right]$ by X-ray diffraction studies.

Experimental. Synthesis. The dibasic tridentate Schiff base ligand, viz., (Z)-4-(((2-hydroxy phenyl)amino)phenyl) methylene)-3-methyl-1-phenyl-1H-pyrazol-5(4H)-one $\left(\mathrm{H}_{2} \mathrm{~L}\right)(370 \mathrm{mg}, 1 \mathrm{mmol})$

(C) Gowri M., Srinivasan T., Velmurugan D., 2015 


\begin{tabular}{|c|c|}
\hline \multicolumn{2}{|c|}{ Crystal Data and Structure Refinement of the $\left[\mathrm{RuCl}_{3}(\mathrm{CO})\left(\mathrm{PPh}_{3}\right)_{2}\right]$ Complex } \\
\hline Empirical formula & $\mathrm{C} 37 \mathrm{H} 30 \mathrm{Cl} 3 \mathrm{OP} 2 \mathrm{Ru}$ \\
\hline Formula weight & 759.97 \\
\hline Temperature, $\mathrm{K}$ & 293(2) \\
\hline Wavelength, $\AA$ & 0.71073 \\
\hline Crystal system, space group & Monoclinic, $C 2 / c$ \\
\hline Unit cell dimensions $a, b, c, \AA$ & $24.2912(7), 9.5543(3), 15.9568(4)$ \\
\hline$\beta$, deg. & $116.3420(10)$ \\
\hline$V, \AA^{3}$ & $3318.79(16)$ \\
\hline$Z$, calculated density, $\mathrm{g} / \mathrm{cm}^{3}$ & 4, 1.521 \\
\hline Absorption coefficient, $\mathrm{mm}^{-1}$ & 0.840 \\
\hline$F(000)$ & 1540 \\
\hline Crystal size, mm & $0.20 \times 0.20 \times 0.20$ \\
\hline$\theta$ range for data collection, deg & 1.87 to 28.44 \\
\hline Limiting indices $h, k, l$ & $-32 \leq h \leq 32,-12 \leq k \leq 11,-21 \leq l \leq 21$ \\
\hline Reflections collected / unique & $15081 / 4168[R(\mathrm{int})=0.0219]$ \\
\hline Completeness to $\theta=28.44^{\circ}, \%$ & 99.6 \\
\hline Absorption correction & None \\
\hline Refinement method & Full-matrix least-squares on $F^{2}$ \\
\hline Data / restraints / parameters & $4168 / 0 / 201$ \\
\hline Goodness-of-fit on $F^{2}$ & 1.041 \\
\hline Final $R$ indices $[I>2 \sigma(I)]$ & \\
\hline$R$ indices (all data) & $R_{1}=0.0538, w R_{2}=0.1321$ \\
\hline Largest diff. peak and hole, e $/ \AA^{-3}$ & 1.338 and -2.041 \\
\hline CCDC No. & 892627 \\
\hline
\end{tabular}

[5 ] was added to a $\left[\mathrm{Ru}(\mathrm{H})(\mathrm{Cl})(\mathrm{CO})\left(\mathrm{PPh}_{3}\right)_{3}\right]$ solution $(950 \mathrm{mg}, 1 \mathrm{mmol})$ in equal volume mixtures of chloroform and ethyl acetate, and the mixture was refluxed for about $4 \mathrm{~h}$. The expected product $\left[\mathrm{Ru}(\mathrm{CO})\left(\mathrm{PPh}_{3}\right) \mathrm{L}\right]$ was obtained as a green precipitate which was filtered off. The filtrate showed the presence of another product which was found to be different from any of the starting complexes and the expected product. The filtrate resulted in the formation of reddish brown colored transparent crystals on standing. These crystals were subjected to various spectroscopic and X-ray diffraction studies.

FT-IR spectrum. The FT-IR spectrum of the complex was recorded in $\mathrm{KBr}$ pellets using a Perkin Elmer spectrophotometer of the RXI model in the range $400-4000 \mathrm{~cm}^{-1}$.

Single crystal X-ray diffraction. The single crystal X-ray diffraction of the title complex was carried out at the Madras University, Chennai. On the attempt to prepare a ruthenium(II) complex with the pyrazole Schiff base, the title complex $\left[\mathrm{RuCl}_{3}(\mathrm{CO})\left(\mathrm{PPh}_{3}\right)_{2}\right]$, which was obtained accidentally as reddish brown crystals, was subjected to single crystal X-ray diffraction and its structure was solved by the direct method using the SHELXS-97 program [6] and refined by the full-matrix least squares method using SHELXL-97 [6-9] programs.

The main details of the X-ray diffraction study are given in Table 1. The crystallographic data have been deposited with the Cambridge Crystallographic Data Centre (CCDC No. 892627) deposit@ccdc.cam.ac.uk or http.//www.ccdc.cam.ac.uk.data_request/cif).

Results and discussion. The FT-IR spectrum of the $\left[\mathrm{RuCl}_{3}(\mathrm{CO})\left(\mathrm{PPh}_{3}\right)_{2}\right]$ complex gives an indication of the coordination mode of the metal ion with the ligands. The characteristic frequencies of the aromatic $\mathrm{C}-\mathrm{H}$ stretching $\left(3053 \mathrm{~cm}^{-1}\right)$ and bending $\left(856 \mathrm{~cm}^{-1}\right)$ are found in the expected regions. A characteristic band was observed at $1435 \mathrm{~cm}^{-1}$, which was attributed to the triphenyl phosphine 
Bond Lengths $(\AA)$ and Angles (deg.) for the $\left[\mathrm{RuCl}_{3}(\mathrm{CO})\left(\mathrm{PPh}_{3}\right)_{2}\right]$ Complex

\begin{tabular}{|c|c|c|c|c|c|}
\hline \multicolumn{6}{|c|}{ Bond lengths } \\
\hline $\mathrm{Ru}(1)-\mathrm{C}(1)$ & $2.008(5)$ & $C(14)-C(19)$ & $1.393(5)$ & $\mathrm{C}(5)-\mathrm{H}(5)$ & 0.9300 \\
\hline $\mathrm{Ru}(1)-\mathrm{Cl}(1) \# 1$ & $2.3930(12)$ & $C(15)-C(16)$ & $1.400(6)$ & $\mathrm{C}(11)-\mathrm{C}(10)$ & $1.363(6)$ \\
\hline $\mathrm{Ru}(1)-\mathrm{Cl}(1)$ & $2.3930(12)$ & $\mathrm{C}(15)-\mathrm{H}(15)$ & 0.9300 & $\mathrm{C}(11)-\mathrm{H}(11)$ & 0.9300 \\
\hline $\mathrm{Ru}(1)-\mathrm{Cl}(2)$ & $2.413(4)$ & $C(4)-C(5)$ & $1.366(6)$ & $\mathrm{C}(3)-\mathrm{H}(3)$ & 0.9300 \\
\hline $\mathrm{Ru}(1)-\mathrm{P}(1)$ & $2.4194(8)$ & $C(4)-C(3)$ & $1.389(5)$ & $\mathrm{C}(7)-\mathrm{H}(7)$ & 0.9300 \\
\hline $\mathrm{Ru}(1)-\mathrm{P}(1) \# 1$ & $2.4194(8)$ & $\mathrm{C}(4)-\mathrm{H}(4)$ & 0.9300 & $C(18)-C(17)$ & $1.368(8)$ \\
\hline $\mathrm{P}(1)-\mathrm{C}(2)$ & $1.824(3)$ & $C(19)-C(18)$ & $1.383(6)$ & $\mathrm{C}(18)-\mathrm{H}(18)$ & 0.9300 \\
\hline $\mathrm{P}(1)-\mathrm{C}(8)$ & $1.826(3)$ & $\mathrm{C}(19)-\mathrm{H}(19)$ & 0.9300 & $C(9)-C(10)$ & $1.388(6)$ \\
\hline$P(1)-C(14)$ & $1.827(3)$ & $C(16)-C(17)$ & $1.366(8)$ & $\mathrm{C}(9)-\mathrm{H}(9)$ & 0.9300 \\
\hline $\mathrm{C}(1)-\mathrm{O}(1)$ & $0.834(13)$ & $\mathrm{C}(16)-\mathrm{H}(16)$ & 0.9300 & $\mathrm{C}(10)-\mathrm{H}(10)$ & 0.9300 \\
\hline$C(8)-C(9)$ & $1.381(5)$ & $C(12)-C(11)$ & $1.357(7)$ & $\mathrm{C}(13)-\mathrm{H}(13)$ & 0.9300 \\
\hline$C(8)-C(13)$ & $1.382(5)$ & $\mathrm{C}(12)-\mathrm{H}(12)$ & 0.9300 & $\mathrm{C}(17)-\mathrm{H}(17)$ & 0.9300 \\
\hline$C(2)-C(3)$ & $1.387(5)$ & $C(6)-C(5)$ & $1.367(7)$ & & \\
\hline$C(2)-C(7)$ & $1.389(5)$ & $C(6)-C(7)$ & $1.387(6)$ & & \\
\hline$C(14)-C(15)$ & $1.383(5)$ & $\mathrm{C}(6)-\mathrm{H}(6)$ & 0.9300 & & \\
\hline \multicolumn{6}{|c|}{ Bond angles } \\
\hline $\mathrm{C}(1)-\mathrm{Ru}(1)-\mathrm{Cl}(1) \# 1$ & $84.81(3)$ & $\mathrm{C}(3)-\mathrm{C}(2)-\mathrm{P}(1)$ & $122.1(3)$ & $C(12)-C(11)-C(10)$ & $119.2(4)$ \\
\hline $\mathrm{C}(1)-\mathrm{Ru}(1)-\mathrm{Cl}(1)$ & $84.81(3)$ & $C(7)-C(2)-P(1)$ & $119.7(3)$ & $\mathrm{C}(12)-\mathrm{C}(11)-\mathrm{H}(11)$ & 120.4 \\
\hline $\mathrm{Cl}(1) \# 1-\mathrm{Ru}(1)-\mathrm{Cl}(1)$ & $169.61(7)$ & $C(15)-C(14)-C(19)$ & $118.7(4)$ & $\mathrm{C}(10)-\mathrm{C}(11)-\mathrm{H}(11)$ & 120.4 \\
\hline $\mathrm{C}(1)-\mathrm{Ru}(1)-\mathrm{Cl}(2)$ & $180.000(1)$ & $C(15)-C(14)-P(1)$ & $121.7(3)$ & $C(2)-C(3)-C(4)$ & $120.5(3)$ \\
\hline $\mathrm{Cl}(1) \# 1-\mathrm{Ru}(1)-\mathrm{Cl}(2)$ & $95.19(3)$ & $C(19)-C(14)-P(1)$ & 119.2(3) & $\mathrm{C}(2)-\mathrm{C}(3)-\mathrm{H}(3)$ & 119.8 \\
\hline $\mathrm{Cl}(1)-\mathrm{Ru}(1)-\mathrm{Cl}(2)$ & $95.19(3)$ & $C(14)-C(15)-C(16)$ & $120.0(4)$ & $\mathrm{C}(4)-\mathrm{C}(3)-\mathrm{H}(3)$ & 119.8 \\
\hline $\mathrm{C}(1)-\mathrm{Ru}(1)-\mathrm{P}(1)$ & $89.35(2)$ & $\mathrm{C}(14)-\mathrm{C}(15)-\mathrm{H}(15)$ & 120.0 & $C(6)-C(7)-C(2)$ & $120.6(4)$ \\
\hline $\mathrm{Cl}(1) \# 1-\mathrm{Ru}(1)-\mathrm{P}(1)$ & $92.49(3)$ & $\mathrm{C}(16)-\mathrm{C}(15)-\mathrm{H}(15)$ & 120.0 & $\mathrm{C}(6)-\mathrm{C}(7)-\mathrm{H}(7)$ & 119.7 \\
\hline $\mathrm{Cl}(1)-\mathrm{Ru}(1)-\mathrm{P}(1)$ & $87.39(3)$ & $C(5)-C(4)-C(3)$ & $120.5(4)$ & $C(2)-C(7)-H(7)$ & 119.7 \\
\hline $\mathrm{Cl}(2)-\mathrm{Ru}(1)-\mathrm{P}(1)$ & $90.65(2)$ & $C(5)-C(4)-H(4)$ & 119.8 & $C(17)-C(18)-C(19)$ & $120.5(5)$ \\
\hline $\mathrm{C}(1)-\mathrm{Ru}(1)-\mathrm{P}(1) \# 1$ & $89.35(2)$ & $\mathrm{C}(3)-\mathrm{C}(4)-\mathrm{H}(4)$ & 119.8 & $\mathrm{C}(17)-\mathrm{C}(18)-\mathrm{H}(18)$ & 119.8 \\
\hline $\mathrm{Cl}(1) \# 1-\mathrm{Ru}(1)-\mathrm{P}(1) \# 1$ & $87.39(3)$ & $C(18)-C(19)-C(14)$ & $120.4(4)$ & $\mathrm{C}(19)-\mathrm{C}(18)-\mathrm{H}(18)$ & 119.8 \\
\hline $\mathrm{Cl}(1)-\mathrm{Ru}(1)-\mathrm{P}(1) \# 1$ & $92.49(3)$ & $\mathrm{C}(18)-\mathrm{C}(19)-\mathrm{H}(19)$ & 119.8 & $\mathrm{C}(8)-\mathrm{C}(9)-\mathrm{C}(10)$ & $120.5(4)$ \\
\hline $\mathrm{Cl}(2)-\mathrm{Ru}(1)-\mathrm{P}(1) \# 1$ & $90.65(2)$ & $\mathrm{C}(14)-\mathrm{C}(19)-\mathrm{H}(19)$ & 119.8 & $\mathrm{C}(8)-\mathrm{C}(9)-\mathrm{H}(9)$ & 119.7 \\
\hline $\mathrm{P}(1)-\mathrm{Ru}(1)-\mathrm{P}(1) \# 1$ & $178.70(4)$ & $C(17)-C(16)-C(15)$ & $120.4(5)$ & $\mathrm{C}(10)-\mathrm{C}(9)-\mathrm{H}(9)$ & 119.7 \\
\hline $\mathrm{C}(2)-\mathrm{P}(1)-\mathrm{C}(8)$ & $100.13(15)$ & $\mathrm{C}(17)-\mathrm{C}(16)-\mathrm{H}(16)$ & 119.8 & $\mathrm{C}(11)-\mathrm{C}(10)-\mathrm{C}(9)$ & $120.8(4)$ \\
\hline$C(2)-P(1)-C(14)$ & $105.36(16)$ & $\mathrm{C}(15)-\mathrm{C}(16)-\mathrm{H}(16)$ & 119.8 & $\mathrm{C}(11)-\mathrm{C}(10)-\mathrm{H}(10)$ & 119.6 \\
\hline$C(8)-P(1)-C(14)$ & $104.62(15)$ & $C(11)-C(12)-C(13)$ & $120.9(4)$ & $\mathrm{C}(9)-\mathrm{C}(10)-\mathrm{H}(10)$ & 119.6 \\
\hline $\mathrm{C}(2)-\mathrm{P}(1)-\mathrm{Ru}(1)$ & $118.52(11)$ & $\mathrm{C}(11)-\mathrm{C}(12)-\mathrm{H}(12)$ & 119.6 & $C(8)-C(13)-C(12)$ & $120.6(4)$ \\
\hline $\mathrm{C}(8)-\mathrm{P}(1)-\mathrm{Ru}(1)$ & $117.48(11)$ & $\mathrm{C}(13)-\mathrm{C}(12)-\mathrm{H}(12)$ & 119.6 & $\mathrm{C}(8)-\mathrm{C}(13)-\mathrm{H}(13)$ & 119.7 \\
\hline $\mathrm{C}(14)-\mathrm{P}(1)-\mathrm{Ru}(1)$ & $109.23(10)$ & $C(5)-C(6)-C(7)$ & $120.5(4)$ & $C(12)-C(13)-H(13)$ & 119.7 \\
\hline $\mathrm{O}(1)-\mathrm{C}(1)-\mathrm{Ru}(1)$ & $180.000(2)$ & $C(5)-C(6)-H(6)$ & 119.8 & $C(16)-C(17)-C(18)$ & $120.0(4)$ \\
\hline $\mathrm{C}(9)-\mathrm{C}(8)-\mathrm{C}(13)$ & $118.0(3)$ & $\mathrm{C}(7)-\mathrm{C}(6)-\mathrm{H}(6)$ & 119.8 & $C(16)-C(17)-H(17)$ & 120.0 \\
\hline $\mathrm{C}(9)-\mathrm{C}(8)-\mathrm{P}(1)$ & $118.5(3)$ & $C(4)-C(5)-C(6)$ & $119.8(4)$ & $\mathrm{C}(18)-\mathrm{C}(17)-\mathrm{H}(17)$ & 120.0 \\
\hline $\mathrm{C}(13)-\mathrm{C}(8)-\mathrm{P}(1)$ & $123.5(3)$ & $C(4)-C(5)-H(5)$ & 120.1 & & \\
\hline$C(3)-C(2)-C(7)$ & $118.2(3)$ & $C(6)-C(5)-H(5)$ & 120.1 & & \\
\hline
\end{tabular}




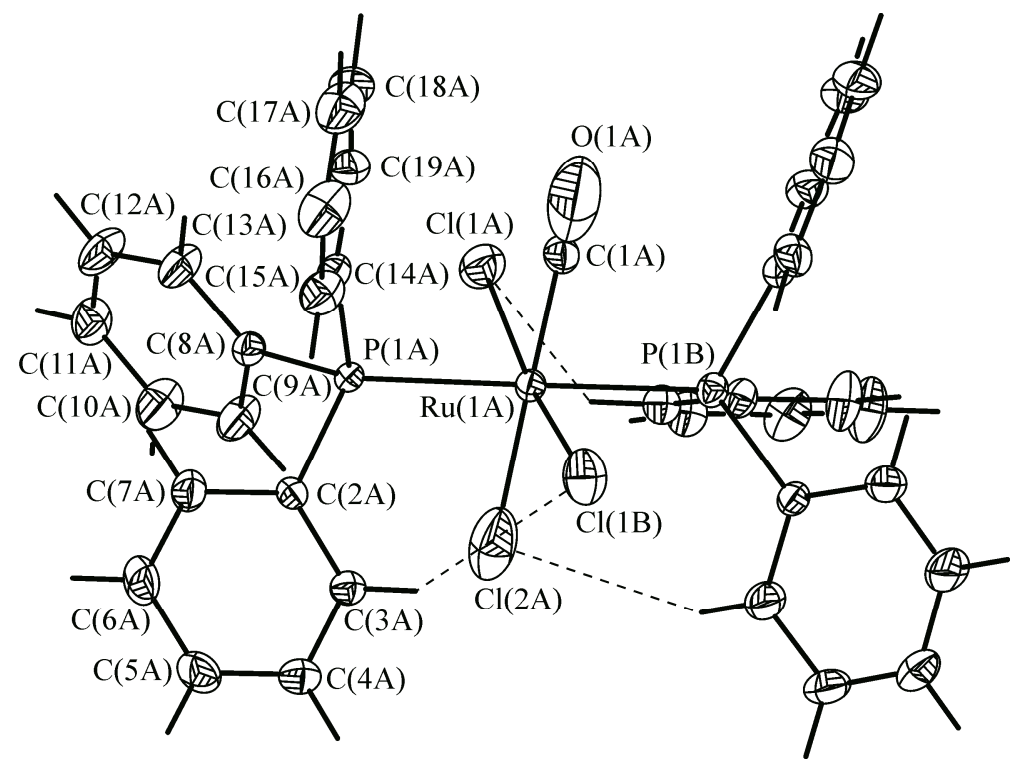

Fig. 1. The molecular structure of $\left[\mathrm{RuCl}_{3}(\mathrm{CO})\left(\mathrm{PPh}_{3}\right)_{2}\right]$ complex, showing displacement ellipsoids drawn at the $30 \%$ probability level. $\mathrm{H}$ atoms are removed for structure clarity

group [ 10 ]. The presence of carbon monoxide as a ligand terminally coordinated to the metal is evident from the presence of a high-intensity sharp peak at $1945 \mathrm{~cm}^{-1}$ [11].

The title complex crystallizes in the monoclinic space group $C 2 / c$ with the cell parameters $a=24.2912(7) \AA, b=9.5543(3) \AA, c=15.9568(4) \AA, \alpha=90.00(0)^{\circ}, \beta=116.342(1)^{\circ}, \gamma=90.00(0)^{\circ}$, $\mathrm{Z}=4, M_{\mathrm{r}}=759.97$, and $V=3318.79(17) \AA^{3}$. The structure was solved by direct methods using SHELXS-97 and refined by the full-matrix least squares method using SHELXL-97 programs [6]. The final $R$-factor value is 0.0471 with a GOOF value of 1.041 for 4168 independent reflections. The asymmetric unit of the title complex $\left[\mathrm{RuCl}_{3}(\mathrm{CO})\left(\mathrm{PPh}_{3}\right)_{2}\right]$ contains one half of the molecule, the complete molecule being generated by the operation with the crystallographic rotation axis (symmetry code: (i) $-x+2, y,-z+1 / 2)$. The angles around the $\mathrm{P} 1$ atom $\left(\mathrm{C} 2-\mathrm{P} 1-\mathrm{C} 8=100.13(15)^{\circ}, \mathrm{C} 2-\mathrm{P} 1-\right.$ $\mathrm{C} 14=105.36(16)^{\circ}$ and $\left.\mathrm{C} 8-\mathrm{P} 1-\mathrm{C} 14=104.62(15)^{\circ}\right)$ deviate from the ideal tetrahedral values, which may be due to a steric interaction between benzene rings and the $\mathrm{Ru}$ atom. The molecular structure of the $\left[\mathrm{RuCl}_{3}(\mathrm{CO})\left(\mathrm{PPh}_{3}\right)_{2}\right]$ complex with displacement ellipsoids drawn at the $30 \%$ probability level is shown in Fig. 1. No classical hydrogen bond was found in this complex.

Out of the three chloride ligands, two of them are found to be involved in intramolecular halogen interactions with the phenyl ring hydrogen atoms because of their proximity and the inclination angle, and this explains the increased stability of the complex. The intramolecular halogen interactions are given by $\mathrm{C} 3-\mathrm{H} 3 \ldots \mathrm{Cl} 1\left(\mathrm{H} \ldots \mathrm{Cl}=2.64\right.$ and the angle $\mathrm{C} 3-\mathrm{H} 3 \ldots \mathrm{Cl} 1=132^{\circ}$ with the symmetry code of $2-x, y, 1 / 2-z)$ and $\mathrm{C} 9-\mathrm{H} 9 \ldots \mathrm{Cl} 2\left(\mathrm{H} \ldots \mathrm{Cl}=2.82\right.$ and the angle $\left.\mathrm{C} 9-\mathrm{H} 9 \ldots \mathrm{Cl} 2=145^{\circ}\right)$, which results in two pseudo six-membered ring structures. The crystal packing of the title complex viewed down the $c$ axis with all hydrogen atoms is shown in Fig. 2.

Conclusions. We have reported the FT-IR and single crystal X-ray diffraction analyzes of the novel $\mathrm{Ru}(\mathrm{III})$ complex $\left[\mathrm{RuCl}_{3}(\mathrm{CO})\left(\mathrm{PPh}_{3}\right)_{2}\right]$. We have explained the structure of the ruthenium complex with the intramolecular halogen interactions. Based on all the above results, it may be further concluded that these by-product crystals are formed by the catalytic behavior of the expected product obtained in the same reaction of carrying out the oxidation of $\mathrm{Ru}(\mathrm{II})$ to $\mathrm{Ru}(\mathrm{III})$. The synthesis of various metal complexes and the evaluation of their catalytic activities are the ongoing project in our laboratory and the results will be published in due course. 


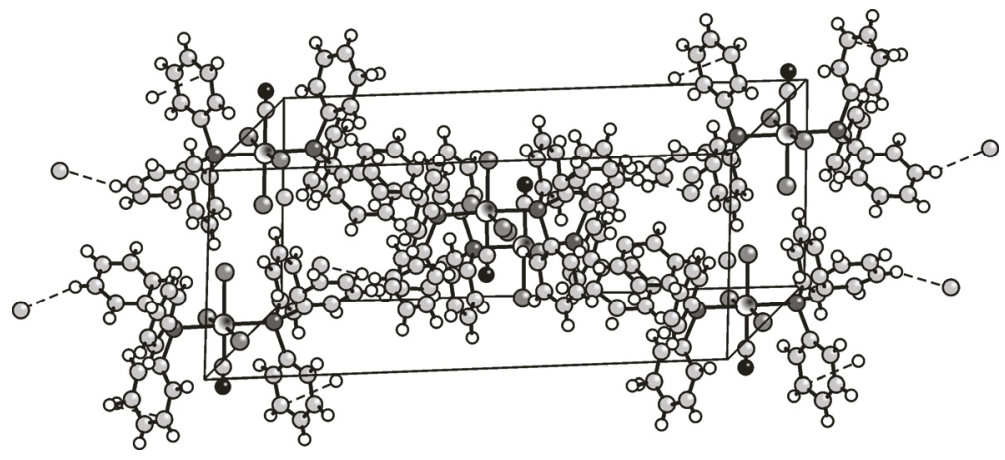

Fig. 2. The crystal packing of $\left[\mathrm{RuCl}_{3}(\mathrm{CO})\left(\mathrm{PPh}_{3}\right)_{2}\right]$ complex viewed down $c$ axis

$\mathrm{T}$ a b 1 e 3

Atomic Coordinates $\left(\times 10^{4}\right)$ and Equivalent Isotropic Displacement Parameters $\left(\AA^{2} \times 10^{3}\right)$ for the $\left[\mathrm{RuCl}_{3}(\mathrm{CO})\left(\mathrm{PPh}_{3}\right)_{2}\right]$ Complex. U(eq) is Defined as One Third of the Trace of the Orthogonalized $U_{i j}$ Tensor

\begin{tabular}{l|c|c|l|c||l|l|l|l|r}
\hline Atom & $x$ & $y$ & $z$ & $U(\mathrm{eq})$ & Atom & $x$ & $y$ & $z$ & $U(\mathrm{eq})$ \\
\hline $\mathrm{Ru}(1)$ & 10000 & $1721(1)$ & 2500 & $27(1)$ & $\mathrm{C}(12)$ & $8959(3)$ & $2127(5)$ & $5184(3)$ & $59(1)$ \\
$\mathrm{P}(1)$ & $9066(1)$ & $1692(1)$ & $2692(1)$ & $26(1)$ & $\mathrm{C}(6)$ & $7363(2)$ & $3463(6)$ & $1360(4)$ & $67(2)$ \\
$\mathrm{Cl}(1)$ & $10552(1)$ & $1495(1)$ & $4163(1)$ & $61(1)$ & $\mathrm{C}(5)$ & $7392(2)$ & $4233(5)$ & $659(3)$ & $54(1)$ \\
$\mathrm{Cl}(2)$ & 10000 & $4247(4)$ & 2500 & $98(1)$ & $\mathrm{C}(11)$ & $9132(2)$ & $3477(5)$ & $5421(3)$ & $53(1)$ \\
$\mathrm{C}(1)$ & 10000 & $-381(6)$ & 2500 & $44(1)$ & $\mathrm{C}(3)$ & $8431(2)$ & $3487(4)$ & $1162(2)$ & $36(1)$ \\
$\mathrm{C}(8)$ & $9111(2)$ & $2337(4)$ & $3798(2)$ & $31(1)$ & $\mathrm{C}(7)$ & $7865(2)$ & $2689(6)$ & $1965(3)$ & $56(1)$ \\
$\mathrm{C}(2)$ & $8406(2)$ & $2686(4)$ & $1870(2)$ & $32(1)$ & $\mathrm{C}(18)$ & $8991(2)$ & $-2472(5)$ & $3197(4)$ & $59(1)$ \\
$\mathrm{C}(14)$ & $8796(2)$ & $-109(3)$ & $2609(2)$ & $32(1)$ & $\mathrm{C}(9)$ & $9296(3)$ & $3701(5)$ & $4054(3)$ & $4054(3)$ \\
$\mathrm{C}(15)$ & $8286(2)$ & $-586(5)$ & $1834(3)$ & $48(1)$ & $\mathrm{C}(10)$ & $9299(3)$ & $4265(5)$ & $4858(4)$ & $66(1)$ \\
$\mathrm{C}(4)$ & $7924(2)$ & $4262(4)$ & $565(3)$ & $46(1)$ & $\mathrm{C}(13)$ & $8946(2)$ & $1549(4)$ & $4377(3)$ & $49(1)$ \\
$\mathrm{C}(19)$ & $9147(2)$ & $-1069(4)$ & $3296(3)$ & $45(1)$ & $\mathrm{C}(17)$ & $8491(3)$ & $-2937(5)$ & $2423(4)$ & $70(2)$ \\
$\mathrm{C}(16)$ & $8137(3)$ & $-2011(6)$ & $1745(4)$ & $67(1)$ & $\mathrm{O}(1)$ & 10000 & $-1254(14)$ & 2500 & $151(4)$
\end{tabular}

\section{REFERENCES}

1. Hartwig J.F. Organotransition Metal Chemistry from Bonding to Catalysis, University Science Books, New York, 2010.

2. Crabtree R.H. The Organometallic Chemistry of the Transition Metals, 4th ed., 2005.

3. Garrou Ph.E. // Chem. Rev. - 1985. - 85. - P. $171-185$.

4. Ledger A.E., Moreno A., Ellul C.E., Mahon M.F., Pregosin P.S., Whittlesey M.K., Williams J.M. et al. // Inorg. Chem. - 2010. - 16, N 49. - P. $7244-7256$.

5. Gowri M., Jayabalakrishnan C., Srinivasan T., Velmurugan D. et al. // J. Mol. Cryst. Liq. Cryst. - 2012. -569. - P. $151-161$.

6. Sheldrick G.M. SHELXS-97 and SHELXL. Program for Refinement of Crystal Structures, University of Gottingen, Germany, 1997.

7. Bruker. APEX2, SAINT and SADABS, AXS Inc., Madison, Wisconsin, USA, 2008.

8. Farrugia L.J. // J. Appl. Crystallogr. - 2012. - 45. - P. 849 - 854.

9. Spek A.L. // Acta Crystallogr. - 2009. - 65. - P. 148 - 155.

10. El-Shahawi M.S., Shoair A.F. et al. // Spectrochim. Acta. - 2004. - 60A. - P. $121-127$.

11. Gopinathan S., Unny I.R., Deshpande S.S., Gopinathan C. et al. // Ind. J. Chem. - 1986. - 25A. - P. 1015 1022. 